$4-2008$

\title{
Introduction to Special Issue on Unified Family Courts
}

Barbara A. Babb

University of Baltimore School of Law, bbabb@ubalt.edu

Gloria Danziger

University of Baltimore School of Law, gdanziger@ubalt.edu

Follow this and additional works at: http://scholarworks.law.ubalt.edu/all_fac

Part of the Courts Commons, and the Family Law Commons

\section{Recommended Citation}

Barbara A. Babb \& Gloria Danziger, Introduction to Special Issue on Unified Family Courts, 46 Family Court Review 224 (2008)

This Article is brought to you for free and open access by the Faculty Scholarship at ScholarWorks@University of Baltimore School of Law. It has been accepted for inclusion in All Faculty Scholarship by an authorized administrator of ScholarWorks@University of Baltimore School of Law. For more information, please contact snolan@ubalt.edu. 


\title{
INTRODUCTION TO SPECIAL ISSUE ON UNIFIED FAMILY COURTS
}

\author{
Barbara A. Babb and Gloria Danziger
}

The articles in this special issue of the Family Court Review (FCR) resulted from a major national conference in Baltimore on May 3-4, 2007. Co-sponsored by the American Bar Association (ABA) and the University of Baltimore School of Law's Center for Families, Children and the Courts (CFCC), the "Summit on Unified Family Courts: Serving Children and Families Efficiently, Effectively, and Responsibly" brought together representatives from over twenty-five states to discuss issues critical to the development of unified family courts (UFCs).

The 2007 Summit was a follow-up conference to the ABA's "Summit on Unified Family Courts: Exploring Solutions for Families, Women and Children in Crisis," held in Philadelphia on May 14-16, 1998. That conference was a major success and spearheaded a number of initiatives within the ABA to promote and nurture UFCs around the country.

While the Philadelphia Summit acted as a catalyst for justice system reform, it did not - and could not - address all the issues central to the development of UFCs. In the years following the conference, as communities moved forward with plans to establish UFCs, judicial leaders sought technical expertise and other resources to support their efforts. Justice system reformers faced significant and critical needs that were not met, including, for example, guidance regarding collaborative and cross-disciplinary approaches to address the nonlegal needs of families and children in crisis within the context of a UFC, the development of standards and measures by which to assess the operation of a UFC, and suggestions to apply the successes and challenges of existing pilot sites to a more extensive UFC initiative.

Reacting to these expressed needs, the ABA's Standing Committee on Substance Abuse and its Coordinating Council on Unified Family Courts, along with the University of Baltimore's CFCC, proposed a follow-up conference to the 1998 Summit. In February 2006, the ABA Board of Governors approved the proposal to convene another Summit based on the same model used for the 1998 conference. The proposed conference was intended to serve as a vehicle to bring together legal experts, judges, attorneys, academics, and community leaders.

The success of the 2007 Summit exceeded the expectations of its planners and organizers. Over 150 representatives from twenty-five states attended plenary and breakout sessions that covered a wide range of issues critical to the development of UFCs: services and accountability, the role of judicial leadership, structural choices involved in establishing a UFC, domestic violence concerns, collaboration with state and local bar associations, court-based pro bono projects for self-represented litigants, and substance abuse, to name a few. 
The common theme among the many and diverse issues raised and addressed during the 2007 Summit was that the design and administration of family courts should help families traverse difficult periods in their lives. ABA President Karen Mathis, who opened the Summit and designated it as a presidential initiative during her tenure, focused on the children in the families who fill court systems. Mathis pointed out that the ABA recognized the importance of UFCs in meeting the legal and protection challenges of children and families by approving policy in 1980 recommending that state court systems establish UFCs.

In order to provide a contextual background for the 2007 Summit, Professor Barbara Babb presented an important overview and state-by-state analysis of family justice systems around the country. Updating her 1998 and 2002 comprehensive national surveys, she once again examined various aspects of each state's family justice system.

Another theme throughout the conversations at the 2007 Summit was the importance of judicial leadership in relation to UFCs. Professor Jane Spinak examined the role and responsibilities of UFC judges. She addressed the appropriateness and effectiveness of a judge to assume the role of "problem solver." Professor Spinak drew informative parallels among the early juvenile court, drug courts, other problem-solving courts, and UFCs to point out both strengths and weaknesses of the UFC model.

The Honorable David Young provided a compelling example of judicial leadership as the luncheon speaker on the second day of the 2007 Summit. Accepting the Scripps Howard Foundation-American Bar Association Award for Distinguished Service to Literacy, he urged all Summit participants to become involved in helping children and families at a time of crisis in family court.

From a practitioner's point of view, many attending the 2007 Summit agreed that UFCs served the needs of their clients most effectively by offering an array of services and by justice system participants acting as problem solvers. Randall Kessler, an attorney in Atlanta, Georgia, offered a firsthand account of his experiences practicing in the UFC pilot project in Atlanta. According to Kessler, judges often helped attorneys reach closure by various methods, including case evaluations, status conferences and pretrial conferences. Kessler provided several anecdotal case studies illustrating how UFCs offered specific advantages to the parties involved in a family law case.

Kessler's case studies indicated that one of the most powerful strengths of the UFC model was its problem-solving focus. Summit participants discussed court-provided and court-referred services as an integral component of this approach, including, for example, substance abuse counseling and treatment referrals, supervised visitation programs, family mediation, self representation projects, children's groups, and parenting seminars. Professor Irwin Sandler, Professor Jeffrey Cookston, Jonathan Miles, and Professor Sanford Braver examined ways that courts deliver programs designed to improve the quality of parenting by mothers and fathers and to strengthen child well-being in divorce cases. They studied the implications for the court of children's mental health problems, the warmth of their relationship with their noncustodial father and custodial mother, and the level of conflict between the parents.

Participants at the 2007 Summit discussed comprehensive subject matter jurisdiction, a hallmark of the UFC model, calling for all family-related cases to be heard by a specialized and separate family court in a position to fashion creative and effective legal outcomes. Judith Moran argued that the case of Terri Schiavo, characterized by fractious and tragic family infighting and a protracted, painful court battle, was most appropriate for adjudication within a UFC. While this required expanding family court subject matter jurisdiction in many states, Moran elucidated how UFCs were best equipped to handle end-of-life 
issues. Her article also looked at another type of intervention, mediation, as an alternative to litigation for end-of-life issues.

There was substantial discussion, both formally and informally, at the 2007 Summit regarding the challenges facing communities to establish and continue UFCs. First and foremost among these issues was funding. Many court systems looked to state legislatures for funding, with budgets nearly always stretched to capacity or faced with cutbacks. The Honorable Judith Kreeger provided invaluable guidance and advice on the art of "grantsmanship" - how to seek funding from private foundations and other public funding sources in order to create, operate, and evaluate new court initiatives.

The sessions at the 2007 Summit accounted for other types of challenges faced by courts considering and implementing the UFC model. In a report from John Greacen to the Honorable Stephanie Domitrovich, the ways in which states reported to have UFCs deal with issues that may exacerbate rather than improve the problems of families and children in court were examined. Based on a survey of sixteen states by the Children and Family Law Committee of the National Conference of State Trial Judges, Greacen's report focused on the implications of the UFC model on confidentiality, due process, and judicial disqualification.

The articles in this special issue of FCR represent only some of the outstanding work resulting from the 2007 "Summit on Unified Family Courts: Serving Children and Families Efficiently, Effectively, and Responsibly." Given the space limitations in this special issue, there are many more conversations about UFCs than there is room to print. In June 2008, the University of Baltimore's CFCC plans to publish a comprehensive Summit report, including summaries of each plenary and workshop session and articles by speakers and other experts in the field of family court reform. We know that this wonderful compendium can serve as an invaluable resource, and we are honored to be the guest editors.

Barbara A. Babb is an associate professor of law and the director of the Center for Families, Children and the Courts, University of Baltimore School of Law, Baltimore, Maryland

Gloria Danziger is a senior fellow at the Center for Families, Children and the Courts, University of Baltimore School of Law, Baltimore, Maryland 